\title{
CONGENITAL HYPERTHYROIDISM: AUTOPSY REPORT
}

\author{
Marcus Aurelho de Lima, Lília Beatriz Oliveira, Neiva Paim and \\ Maria de Fátima Borges
}

LIMA, M. A. de et al. - Congenital hyperthyroidism: autopsy report. Rev Hosp Clín Fac Med S Paulo, 54 (3): 103 - 106 , 1999.

SUMMARY: We report the autopsy of a stillborn fetus with congenital hyperthyroidism born to a mother with untreated Graves' disease, whose cause of death was congestive heart failure.

The major findings concerned the skull, thyroid, heart, and placenta. The cranial sutures were closed, with overlapping skull bones. The thyroid was increased in volume and had intense blood congestion. Histological examination showed hyperactive follicles. The heart was enlarged and softened, with dilated cavities and hemorrhagic suffusions in the epicardium. The placenta had infarctions that involved at least $20 \%$ of its surface, and the vessels of the umbilical cord were fully exposed due to a decrease in Wharton 's jelly.

Hyperthyroidism was confirmed by the maternal clinical data, the fetal findings of exophthalmia, craniosynostosis, and goiter with signs of follicular hyperactivity.

Craniosynostosis is caused by the anabolic action of thyroid hormones in bone formation during the initial stages of development. The delayed initiation of treatment in the present case contributed to the severity of fetal hyperthyroidism and consequent fetal death.

DESCRIPTORS: Congenital hyperthyroidism. Graves' disease. Thyroid. Craniosynostosis. Autopsy.

Graves' disease (GD) is characterized by hyperthyroidism clinically manifesting as hyperfunctioning diffuse hyperplastic goiter, at times accompanied by ophthalmopathy and dermopathy ${ }^{17}$. In nonendemic goiter areas, GD is the second most common thyroid disease. It occurs at all ages, but is more common during the 3 rd and 4th decades of life ${ }^{8}$. The incidence of thyrotoxicosis during pregnancy is low (0.04 to $1.4 \%$ ), and only 1 in 70 infants born to thyrotoxic mothers develops signs and symptoms of hyperthyroidism ${ }^{10,11}$. Among newborns with hyperthyroidism, 60 $\%$ present transitory or self-limiting symptoms, $20 \%$ die as a consequence of heart failure, and the remaining $20 \%$ continue to present symptoms for more than 6 months, requiring more prolonged, though transitory, treatment ${ }^{10}$.

Having had the opportunity to autopsy a stillborn fetus with congenital hyperthyroidism who died of heart failure, we thought it would be justified to describe this case because of its rarity and because of the contribution its description may make to a better understanding of the disease.

\section{CASE REPORT}

A 27-year old white housewife sought the Gynecology and Obstetrics Outpatient Clinic of the

From "Dep. de Endocrinologia da Faculdade de Medicina do Triângulo Mineiro Uberaba - M.G."
Faculty of Medicine of Triângulo Mineiro (FMTM) in Uberaba, Minas Gerais State, Brazil for prenatal care during the 16th week of pregnancy. She was in good general condition, with arterial pressure of $130 / 70$ $\mathrm{mmHg}$, and a thyroid enlarged to twice the normal size, attributed to pregnancy. At the gestational age of 32 weeks and 3 days, the patient had exophthalmia and increased thyroid hormone concentrations: free T4, 5.2 $\mathrm{ng} / \mathrm{dl}$ (normal range: $0.8-2.3 \mathrm{ng} / \mathrm{dl}$ ), and TSH, $0.03 \mathrm{mIU} / \mathrm{ml}$ (normal range $=0.34-4.5 \mathrm{mIU}$ ). Weight was 62.8 $\mathrm{kg}$, height $152 \mathrm{~cm}$, body mass index was $27.18 \mathrm{~kg} / \mathrm{m} 2$, arterial pressure $150 \times 90 \mathrm{mmHg}$, and heart rate 96 systoles/minute. Treatment with propylthiouracil $(150 \mathrm{mg}$ every 8 hours) was started. One week later, with a gestational age of 36 weeks 


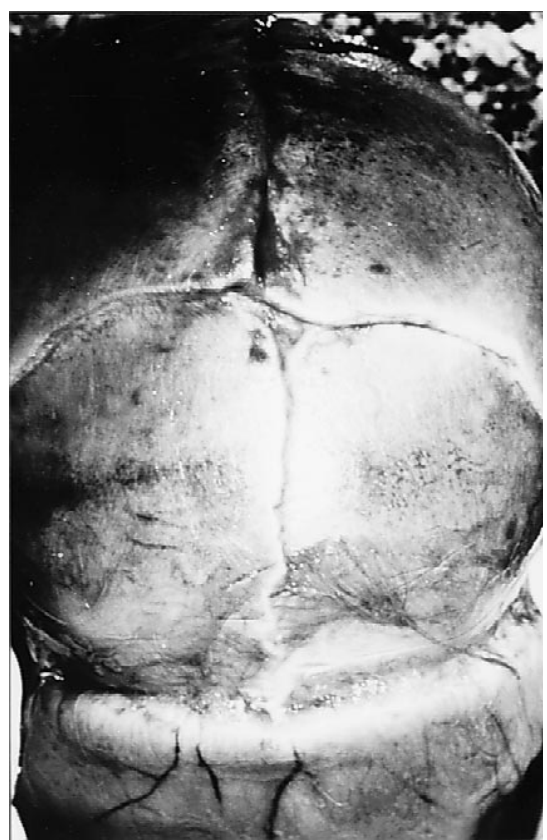

Figure 1 - Skull presenting closed sutures and overlapping bones.

and 3 days according to the date of last menstruation and of 37 weeks and 4 days according to ultrasonography, the patient was admitted to the Teaching Hospital of FMTM, complaining of cramp-like pain in the lower abdomen lasting 12 hours. Gynecologic examination showed signs of labor, and the patient gave birth to a stillborn infant.

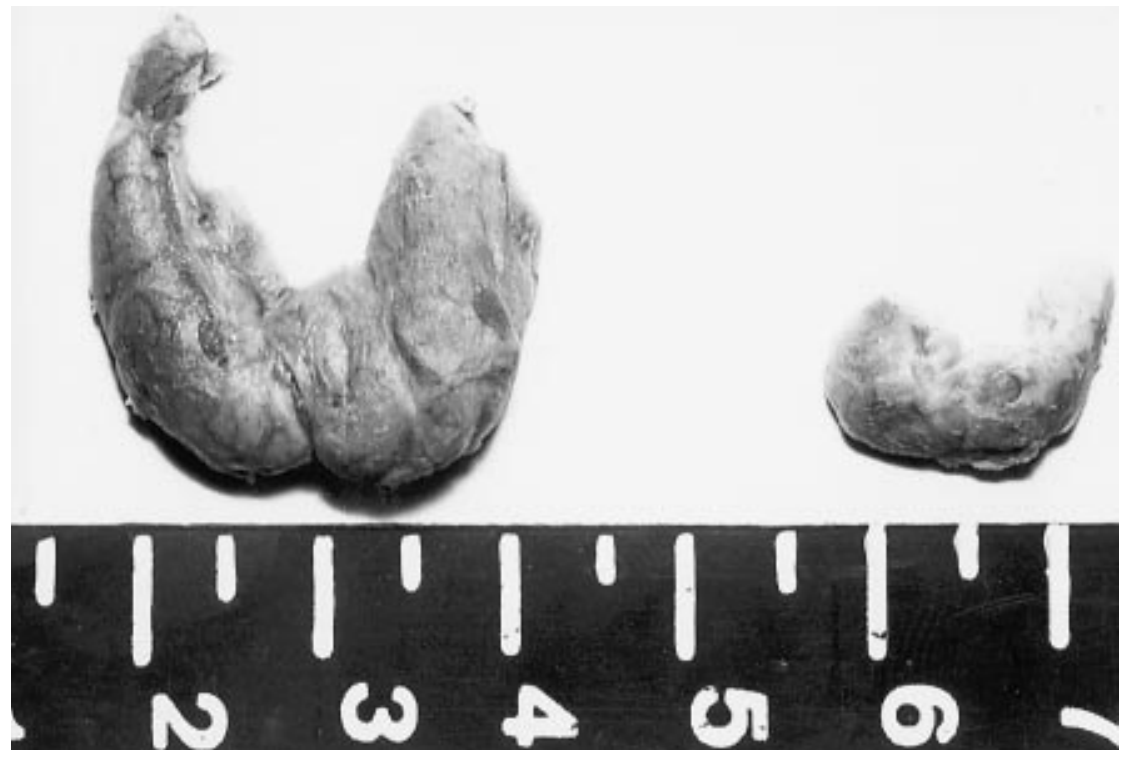

Figure 2 - Thyroid of the stillborn fetus described in the present report. Note the diffuse enlargement on the left compared to the thyroid of another stillborn fetus of the same gestational age (36 weeks). had hemorrhagic suffusions in the epicardium (Figure 4). The pericardiac fluid was citrine-yellow and slightly increased.

The spleen was enlarged (weight, $23 \mathrm{~g}$ - normal weight $9 \mathrm{~g} \pm 4 \mathrm{~g}$ ), congested and with hematopoietic focal points observed by microscopy.

The placenta was normal in volume (weight, $460 \mathrm{~g}$ ) and had both recent and earlier infarctions involving less than $20 \%$ of its surface. Microscopy showed fibrin deposits and congestion of fetal blood vessels.

The umbilical cord vessels were fully exposed due to a decrease in the amount of Wharton's jelly. The remaining organs had only polyvisceral congestion.

\section{DISCUSSION}

We report the autopsy findings for a stillborn infant with congenital hyperthyroidism, whose cause of death appeared to be congestive heart failure. Hyperthyroidism was confirmed on the basis of maternal clinical data, and on the fetal findings of exophthalmia, early closure of cranial sutures (premature craniosynostosis), and goiter with signs of follicular hyperactivity.

Craniosynostosis has been observed as an isolated sign or as part of systemic disease and is one of the complications of congenital or juvenile hyperthyroidism, being observed more commonly in prolonged thyrotoxicosis ${ }^{7}$. Thyroid hormones are anabolic agents acting on bone formation during the early stages of childhood development, and their excessive concentrations act as a factor of acceleration of skeletal maturation and of closure of cranial sutures in children ${ }^{1}$.

These hormones increase bone formation directly through nuclear osteoblast receptors ${ }^{18}$, or indirectly through local growth factors such as insulin-growth factor-I (IGF-I) ${ }^{15,23}$. The hormones also increase IGF-I protein content ${ }^{14}$ and IGF-mRNA content $^{22}$ and bind to the nuclear 


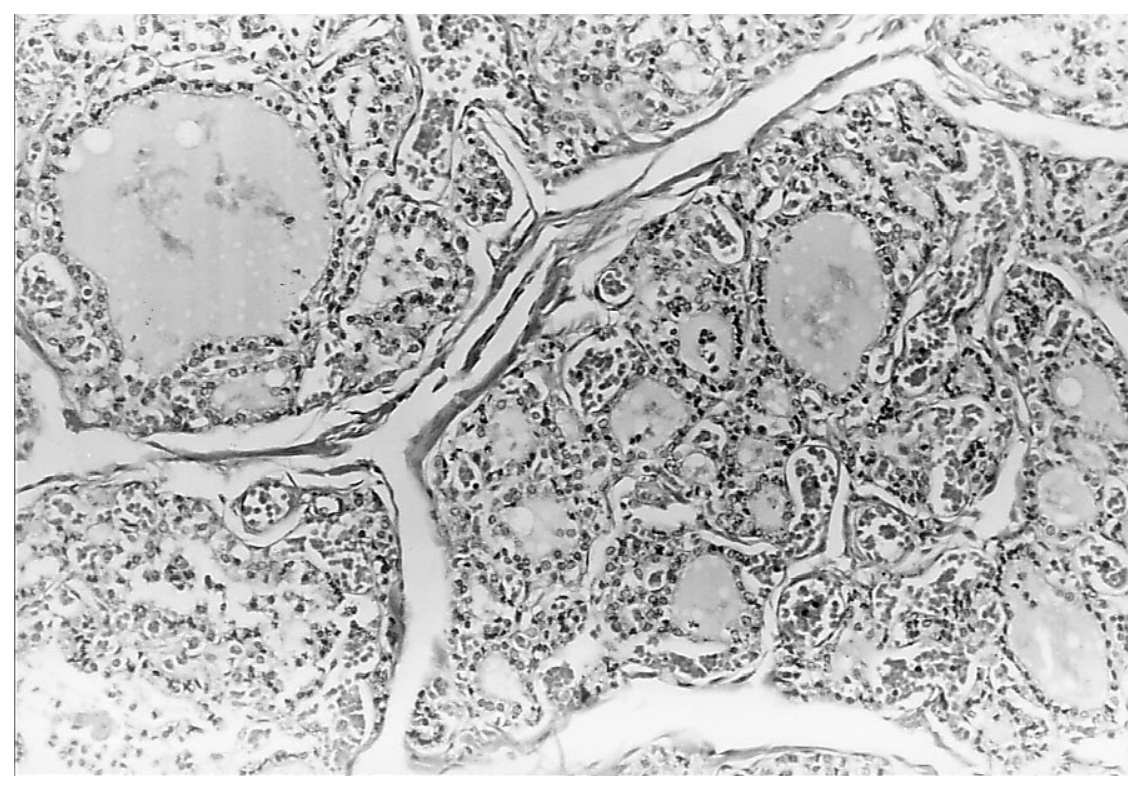

Figure 3 - Photomicrograph of the thyroid's follicles of medium dimensions with intense activity indicated by the large number of reabsorption vacuoles and tall lining epithelium (HE, 100x).

receptors of bone, directly stimulating bone formation ${ }^{13,18}$. IGF-I is mainly produced by osteoblasts ${ }^{4}$ and induces bone formation by stimulating DNA and bone matrix synthesis or by reducing collagen degradation $^{5,16}$. In view of the fact that IGF-I increases cortical bone formation ${ }^{21}$, the sagittal suture may be more influenced than other sutures. Histological

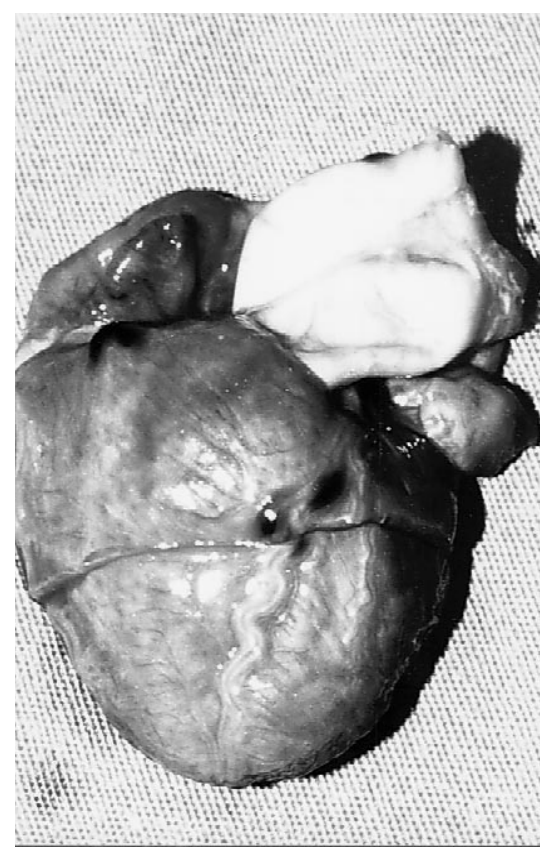

Figure 4 - Globally enlarged heart due to intense dilatation of the cavities. analysis shows that the suture fissure is filled with mesenchymal tissue similar to the exchange layer of long bone periosteum ${ }^{2}$. This property of long bones is involved in the general progress of osteogenesis and proliferation of intervening soft tissues ${ }^{24}$. There are some reports of premature craniosynostosis with changes in thyroid hormones. Robinson et al. ${ }^{19}$ old patient with Graves' disease with premature total fusion of the sagittal, coronal, and lambdoid sutures. In the case reported here, as illustrated in Figure 1, not only the sagittal suture but also the coronal and lambdoid sutures were prematurely closed, with overlap of the bones at these levels.

Although this was not observed in the present case, the brains of fetuses with hyperthyroidism may present ventriculomegaly represented by in vacuum hydrocephaly secondary to the absence of normal cerebral growth. The delayed brain development is a result of the premature arrest of cell division and the accelerated rate of neuron differentiation ${ }^{12}$.

After a careful review of the history of the mother, we considered the diagnosis of Graves' disease in the eighth month of pregnancy to be late, a fact possibly attributable to the difreported the first case of a two-month ficulty in diagnosing hyperthyroidism that starts during pregnancy, especially in its discrete and moderate forms, since the common findings of thyroid hyperfunction are frequently similar to typical changes occurring during pregnancy, i.e., increased cardiac overload, tachycardia, hyperemesis, and pretibial edema. However, the weight loss that characterizes hyperthyroidism is less evident due to the weight gain typical of pregnancy ${ }^{20}$.

Disease duration, early diagnosis, and the institution of appropriate treatment are factors that affect fetal prognosis 9 . The late beginning of treatment in the present case contributed to the severity of fetal hyperthyroidism and to fetal death ${ }^{6}$. Neonatal thyrotoxicosis is the result of transplacental transfer of immunoglobulins that stimulate the thyroid, an event that occurs even in mothers treated months or years before pregnancy. This condition is associated with a mortality rate of $16 \%{ }^{10}$.

Another interesting autopsy findings was the exposure of umbilical cord vessels due to the reduction of Wharton's jelly. This abnormality may involve the umbilical cord in part or as a whole, possibly leading to vessel compression and fetal death. These cords are more frequently observed in fetuses with retarded growth and in preeclampsia, but unknown causes may also to exist ${ }^{3}$. In the present case, the condition involved the entire cord, and no signs of vessel compression or rupture were observed. On the other hand, we do not know if there is any relationship between this finding and hyperthyroidism.

In view of the rare occurrence of a stillborn fetus with hyperthyroidism, we felt that it would be of extreme importance to study the pathologic changes in a fetus born to a patient with Graves' disease who was not treated in time to prevent the severity of the situation and the fatal outcome, and for which the immediate cause of death seems to have been heart failure due to volume overload, as shown by the macroscopic findings. 
LIMA, M. A. de e col. - Hipertireoidismo Congenital. Rev Hosp Clín Fac Med S Paulo, 54(3): 103 - 106, 1999.

Relata-se necropsia de natimorto com hipertireoidismo congênito, filho de mãe portadora de doença de Graves não tratada, que teve como causa de óbito insuficiência cardíaca congestiva. Os achados fundamentais foram vistos no crânio, tireóide coração e placenta. As suturas cranianas encontravam-se fechadas, com acavalgamento dos ossos cranianos.
A tireóide apresentava aumento de volume e congestão sangüinea intensa e, histologicamente, os folículos mostravam hiperatividade. O coração estava aumentado de volume, amolecido, com cavidades dilatadas e sufusões hemorrágicas no epicárdio. A placenta apresentava infartos que acometiam menos de $20 \%$ da superfície placentária e os vasos do cordão umbilical encontravam-se completamente expostos por diminuição da geléia de Warton.

O hipertireoidismo ficou comprovado pelos dados clínicos maternos, os achados fetais de exoftalmia, craniosinostose prematura e bócio com sinais de hiperatividade folicular.

A craniosinostose é causada pela ação anabólica dos hormônios tireoidianos na formação óssea, nos estágios iniciais do desenvolvimento. O início tardio do tratamento no presente caso contribuiu para severidade do hipertireoidismo fetal e óbito.

DESCRIPTORS: Hipertireoidis-
mo congênito. Doença de Graves.
Tireóide. Graniosinostose. Necropsia.

\section{REFERENCES}

1. AKITA S, NAKAMURA T, HIRANO A et al. - Thyroid hormoneaction on rat calvarial sutures. Thyroid 1994; 4:99-106.

2 ALBERIUS P \& JOHNELL O - Immunohistochemical assessment of cranial suture development in rats. J Anat 1990; 173: 61-8.

3. BENIRSCHKE K \& KAUFMANN P - Anatomy and pathology of the umbilical cord and major fetal vessels. In: BENIRSCHKE K, KAUFFMAN P, eds. - Pathology of the human placenta. 3th ed. New York, Springer, 1995. p. 319.

4. CANALIS E, MCCARTHY T \& CENTRELLA M - Isolation and characterization of insulin-like growth factor I (somatomedin-C) from cultures of fetal rat calvariae. Endocrinol 1988; 122: 22-7.

5. CANALIS E - Effect of insulin-like growth factor I on DNA and protein synthesis in cultured rat calvaria. J Clin Invest 1980; 66: 709.

6. DAVIS LE, LUCAS NJ, HANKINS GDV et al. - Thyrotoxicosis complicating pregnancy. Am J Obs and Gynecol 1989; 160: 63-70.

7. DUGGAN CA, KEENER EB, GAY BB JR. - Secondary craniosynostosis. Am J Radiol 1970; 109:277.

8. FRANSSILA KO - The thyroid. In: LECHAGO J, GOULD VE eds. Bloodworth's endocrine pathology. 3th ed. Baltimore, Williams \& Wilkins, 1997 p.171-247.

9. GIARDINA S, CONTARINI A \& BECCA B - Maternal diseases and congenital malformations. Ann Ist Super Sanità 1993; 29:69-76.

10. HOLLINGSWORTH DR \& MABRY CC - Congenital Graves' disease: four familial cases with long-term follow-up and perspective. Am J Dis Child 1976; 130:148-155.

11 KAPLAN M M - Thyroid disease. In: GLEICHER N ed. Principles and practice of medical therapy in pregnancy. Connecticut, Appleton, 1992. p.321-338.

12. KOPELMAN AE - Delayed cerebral development in twins with congenital hyperthyroidism. Am J Dis Child 1983; 137:842-845.

13. KRIEGER NS, STAPPENBECK TS, \& STERN PH Characterization of specific thyroid hormone receptors in bone. $\mathbf{J}$ Bone Miner Res 1988; 3: 473-8.
14. LAKATOS P, CAPLICE MD, KHANNA V et al. - Thyroid hormones increase insulin-like growth factor I content in the medium of rat bone tissue. J Bone Miner Res 1993; 8:1475-81.

15. LINKHART TA \& KEFFER MJ - Differential regulation of insulin- like growth factor -I (IGF-I) and IGF- II release from cultured neonatal mouse calvaria by parathyroid hormone, transforming growth factor-beta, and 1,25-dihydroxyvitamin D3. Endocrinol 1991; 128: 1511-8.

16. MCCARTHY TL, CENTRELLA M \& CANALIS E - Parathyroid hormone enhances the transcript and polypeptide levels of insulinelike growth factor I in osteoblast-enriched cultures from fetal rat bone. Endocrinol 1989; 124:1247-53.

17. MUNRO DS, DIRMIKIS SM \& HUMPHRIES H - The role of thyroid stimulating immunoglobulins of Graves's disease in neonatal thyrotoxicosis. Br J Obst Gynecol 1978; 85: 837-843.

18. RIZZOLI R, POSTER J \& BURGI U - Nuclear thyroid hormone receptors in cultured bone cells. Metabolism 1986; 35:71-4.

19. ROBINSON DC, HALL R \& MUNRO DS - Graves' disease, an unusual complication: raised intracranial pressure due to premature fusion of skull sutures. Arch Dis Child 1969; 44: 252-7.

20. THOMAS $\mathrm{R} \&$ REID RL - Thyroid disease and reproductive dysfunction: A review. Obstet Gynecol 1987; 70:789-98.

21.TOBIAS JH, CHOW JW \& CHAMBERS TJ - Opposite effects of insulin-like growth factor-I on the formation of trabecular and cortical bone in adult female rats. Endocrinol 1992; 131: 2387-92.

22.HOFER K - Thyroid hormones increase insulin-like growth factor mRNA levels in the clonal osteoblastic cell line MC3T3-E1. FEBS Lett 1994; 345: 67-70.

23. WOLF M, INGBAR SH \& MOSES AC - Thyroid hormone and growth hormone interact to regulate insulin-like growth factor-I messenger ribonucleic acid and circulating levels in the rat. Endocrinol 1989; 125:2905-14.

24. ZIMMERMANN B - Degeneration of osteoblasts involved in intramembranous ossification of fetal rat calvaria. Cell Tissue Res 1992; 267:75-84, 1992.

Received for publication on the 27/05/99 